\title{
Comparative legal analysis of the Directive 2019/1152 of the European Parliament and of the Council of 20 June 2019 on transparent and predictable working conditions in the European Union with the current labour law of all its Member States
}

\author{
Volodymyr Bozhko, ${ }^{1, *}$, Inna Kulchii ${ }^{2}$, and Volodymyr Zadorozhnyy ${ }^{2}$ \\ ${ }^{1}$ Poltava Law Institute of Yaroslav Mudryi National Law University, Poltava, Ukraine \\ ${ }^{2}$ Poltava National Technical Yuri Kondratyuk University, Poltava, Ukraine
}

\begin{abstract}
The article deals with the comparative legal research of the current labour legislation of each of the $28 \mathrm{EU}$ member states with the Directive 2019/1152 of 20 June 2019 on transparent and predictable working conditions in the European Union. The relevance of the research topic is because after the adoption of Council Directive 91/533/EEC in the EU, a number of acts of primary and secondary legislation were adopted that significantly change the content and scope of labour rights of workers. These are, in particular, The Maastricht Treaty, The Treaty of Amsterdam, The Treaty of Nice and the Treaty of Lisbon. Furthermore, on December 7, 2000, the Charter of Fundamental Rights of the European Union was signed, and on December 17, 2017, The European Parliament, the Council and the Commission solemnly proclaimed the European Pillar of Social Rights. As a result, collisions arose between the above Acts and Directive 91/533/EEC, which required the adoption of a new Directive 2019/1152 and a comparative legal analysis of this Directive with the current labour legislation of each of the $28 \mathrm{EU}$ member states.
\end{abstract}

Key words: employee, employer, working conditions, employment contract, labour law.

\section{Introduction}

As Maina Kiai rightfully asserts in a Special Report on the right to freedom of peaceful assembly and the right to freedom of association, submitted in accordance with the Human Rights Council resolution 24/5 at the 71st session of the United Nations General Assembly, proclaimed on September 14, 2016, the modern world and a globalized economy are changing rapidly. Therefore, it is extremely important for the tools that are used to protect labour rights also to change dynamically. A necessary condition for this should be the elimination of outdated and artificial oppositions of labour and human rights in general. Labour rights are human rights, and the ability to exercise those rights in the workplace is a prerequisite for workers to enjoy a broad range of other rights - economic, social, cultural, political or otherwise [1].

\footnotetext{
* Corresponding author: volodya_bozhko@ukr.net
}

(C) The Authors, published by EDP Sciences. This is an Open Access article distributed under the terms of the Creative Commons Attribution License 4.0 (http://creativecommons.org/licenses/by/4.0/). 
Labour rights are proclaimed not only in acts of the United Nations, but also in acts of the European Union. For example, according to the Charter of Fundamental Rights of the European Union, everyone has the right to engage in labour activities and engage in a freely chosen or accepted profession (article 15(1)) [2].

In accordance with $\S 9$ of the Community Charter of Fundamental Social Rights of Workers, declared by President Delors on 8 December 1989 at the European Council, "the conditions of employment of every worker of the European Community shall be stipulated in laws, a collective agreement or in contract of employment, according to arrangements applying in each country".

In pursuance of the Community Charter of Fundamental Social Rights of Workers on October 14, 1991 the European Commission adopted Council Directive 91/533/EEC on employer's obligation to inform employees of the conditions applicable to the contract or employment relationship [3]. The EEC member states were required to bring their Laws into conformity with that Directive by 30 June 1993 at the latest.

From April 21, 2015 to February 21, 2016, the European Commission evaluated the results of the implementation of Council Directive 91/533/EEC by all EU member states [4]. Making a general positive conclusion, the European Commission indicated its following disadvantages: Directive 91/533/EEC does not cover all categories of workers who work under the terms of an employment contract. It does not cover some new forms of employment such as domestic workers, telework, temporary agency work, freelance contracts, employee sharing, on call work, ICT-based mobile work job sharing, voucher-based work, interim management, crowd employment, and portfolio work.

Furthermore, on December 17, 2017 the European Parliament, the Council and the Commission solemnly proclaimed European Pillar of Social Rights in accordance with article 7 (a) of which, "workers have the right to be informed in writing at the start of employment about their rights and obligations resulting from the employment relationship, including on probation period. Any probation period should be of reasonable duration." (Article 5(d) of European Pillar of Social Rights) [5].

This necessitates the adoption of a new Directive, which, on the one hand, would eliminate all these shortcomings of the current Council Directive 91/533/EEC; on the other hand, it would comply with the European Pillar of Social Rights.

That is why, on June 20, 2019, the European Parliament and the Council adopted the Directive 2019/1152 on transparent and predictable working conditions in the European Union [6].

In these conditions, it is extremely relevant to study whether the current labour legislation complies with Directive 2019/1152 for each of the 28 EU member states.

Therefore, the aim of our study is to obtain results in the form of a set of scientific conclusions on the compliance of the current labour legislation of each of the $28 \mathrm{EU}$ member states with Directive 2019/1152. This aim determines the need to solve the following research tasks: to analyze the categories of workers whom the employer is obliged to inform about the conditions of their work; to study the list of information that must be communicated to the employee when applying for a job; to investigate the period during which the employer must inform the employee about the conditions of their work; determine in what form the employer is obliged to inform the employee about it; to analyze the term during which the employer must inform the employee about changes in working conditions. Such a study will help to identify collisions between the Directive 2019/1152 and the labour legislation of each of the $28 \mathrm{EU}$ member states, as well as formulate conclusions and proposals aimed at resolving these collisions. 


\section{Material and methods}

The following materials were used in the preparation of this work: the current labour legislation of the EU and each of the $28 \mathrm{EU}$ member states, aimed at regulating transparent and predictable working conditions.

To achieve the intended goal of the study, various general scientific and special methods of scientific research inherent in legal science were used, in particular, comparative law, historical, dialectical, formal-logical, method of structural-functional analysis.

\section{Results}

Directive 91/533/EEC of 14 October 1991 applies to any worker having an employment contract or employment relationship as defined by the legislation in force in a member state (article 1(1) of this Directive). Thus, the exhaustive list of categories of persons who are covered by that Directive refers is determined by the national law of the member state. However, Directive 2019/1152 of 20 June 2019 sets a minimum amount of rights for workers in the EU who have an employment contract or employment relationship defined by law, collective agreements or practice in each member state, taking into account the case law of the Court of Justice.

It should be pointed out that in accordance with the legal positions of this Court, an essential feature of the employment relationship is that for a certain period of time the employee is a person performing work (providing services) for and under the direction of another person in exchange receiving remuneration [7].

Thus, the scope of persons covered by Directive 2019/1152 has been significantly expanded.

Analysis of the labour laws of all EU member states showed that the vast majority of them have fixed the signs of labour relations that Court of Justice focuses on. In particular, article 32 of the Labour Code of the Republic of Lithuania stipulates that an employment contract is an agreement between an employee and an employer, according to which the employee undertakes to perform a work function under the authority of the employer and in their favour. Further, it was specified that subordination to the employer means the fulfilment of the work function, that is, when the employer has the right to control or manage the work process and the employee complies with the instructions of the employer [8].

In accordance with article 1(1) of the Constitutional Law on Workers of the Kingdom of Spain, approved by the Royal Legislative Decree № 2/2015, employees are persons who voluntarily provide their paid services to other persons under the direction of another person, individual or legal entity, who called the employer [9].

According to the Part 1 of article 2 of the Law on Employment and Industrial Relations of the Republic of Malta, the term 'employee' means any person, who has concluded or is working under a service agreement. Or - any person, who has taken on their personal responsibility to perform any work or service and under the direct supervision and control of another person, including their employer, but excluding the work or service that is performed in a professional capacity or as a contractor for another person, the work or service is not governed by a specific service agreement [10].

Section 1(1) of the Estonian Law "On Employment Contract" states that, basing on an employment contract, an individual (employee) performs work for another person (employer) under his supervision and supervision. The employer pays the employee for their work [11]. Section 6 of the Czech Republic Labour Code states that an employee is an individual who is required to perform dependent work in labour relations [12]. 
However, the labour legislation of other EU member states does not fully comply with the requirements of Directive 2019/1152. So, for example, in §1(1) of the Danish Law "On the obligation of the employer to notify the employee of the conditions of the employment relationship", it is only stated that it applies to all employees [13]. Similar norms contain the Luxembourg Labour Code [14]; the Labour Code of Bulgaria on January 1, 1987, as amended on November 6, 2018 [15]; the Republic of Ireland Employment Conditions Act of April 5, 1994 №5 [16]; the Austrian Employment Contract Law Harmonization Act of July 1, 1993 [17].

Section 2 of the Law of the Republic of Cyprus only states that an employee means "any person who is protected as an employee in accordance with labour law" [18]. True, as noted in the case law of Cyprus, the term "employee" requires that he/she be in an employment relationship and receive remuneration for their work. Receiving wages (performing paid work) is the most important qualification attribute of the concept of "employee" in the labour law of the Republic of Cyprus.

According to the Directive 91/533/EEC, states may exclude from their scope those categories of workers who have a contract or employment relationship, the total duration of which does not exceed one month and/or a working week of no more than eight hours, or accidental and/or of a specific nature, provided that in these cases of non-use it is justified by objective considerations (article 1(2) of Directive). But the Directive 2019/1152 contains a higher level of guarantees for workers, because article 1(3) of this Directive states that it may not apply to workers whose working hours are equal to or less than an average of three hours per week for four weeks. If during the conclusion of the employment contract the duration of work is not stipulated, then such an employee is subject to this Directive.

An analysis of the labour laws of all EU member states showed that in the vast majority of them only those exceptions are proclaimed, which are indicated in Directive 91/533/EEC. For example, in Denmark, the Law applies to all workers whose average working hours exceed 8 hours for more than one month [13]. In accordance with Section 3(1) of the Law of the Republic of Cyprus, its effect does not apply to workers whose labour relationship does not exceed one month, or whose working week is not more than 8 hours [18]. In Austria, in accordance with §2(4) of AVRAG, if the duration of the employment relationship does not exceed one month, or if the employment contract is in writing, the employer is not required to inform the employee in writing [17]. Article 1(3) of the Law of Spain notes the specifics of regulating the service of public servants and personnel of public administration services, institutions and structures of the public sector of the economy [9]. In accordance with Section $1(\S 1)$ of the German law, it does not include workers who perform labour obligations on the basis of an employment contract for less than 400 hours a year, as well as if they work in medical, educational institutions in Germany, or in the family economy [19]. The Swedish Employment Protection Act states that if the duration of the employment contract does not exceed three weeks, the employer is relieved of the obligation to inform. In addition, the employer is exempted from the Law in relation to the following categories of employees: holding managerial positions or comparable to managerial ones; belonging to the family of the employer; employed at work in the household of the employer; which combine work with learning [20].

In accordance with article 2(1) of the Council Directive 91/533/EEC, an employer is obligated to notify workers of the essential elements of contract/employment relationship. They should, in particular, inform employees of the following: the identities of the parties; the place of work; where there is no fixed or main place of work, the principle that the employee is employed at various places and the registered place of business or, where appropriate, the domicile of the employer; the title, grade, nature or category of the work 
for which the employee is employed; or a brief specification or description of the work; the date of commencement of the contract or employment relationship; in the case of a temporary contract or employment relationship, the expected duration thereof; the amount of paid leave to which the employee is entitled or, where this cannot be indicated when the information is given, the procedures for allocating and determining such leave; the length of the periods of notice to be observed by the employer and the employee should their contract or employment relationship be terminated or, where this cannot be indicated when the information is given, the method for determining such periods of notice; the initial basic amount, the other component elements and the frequency of payment of the remuneration to which the employee is entitled; the length of the employee's normal working day or week; where appropriate; the collective agreements governing the employee's conditions of work or in the case of collective agreements concluded outside the business by special joint bodies or institutions, the name of the competent body or joint institution within which the agreements were concluded.

At the same time, in accordance with article 4(2) of Directive 2019/1152, member states are obliged to ensure that employers inform their employees, in addition to the conditions specified in article 2(1) of Directive 91/533/EEC about the following working conditions:

- about the duration and working conditions during the trial period, if one is established;

- about the rights of the employee to training guaranteed by the employer, if any;

- about any arrangements for overtime work and its remuneration. If the work scheme is completely or predominantly unpredictable, the employer must inform the employee about the shift work schedule, the number of guaranteed paid hours and the amount of additional remuneration for the work performed. They must inform about the minimum period of prior notice for which the employee is entitled before the start of the work assignment. If it falls within the competence of the employer, then the name of the social security institutions receiving social contributions and providing any protection with regard to social security provided by the employer.

An analysis of the labour laws of all EU member states showed that the vast majority of them have an obligation to inform only about the information that is specified in Directive 91/533/EEC.

According to article 1(1) of Italian Legislative Decree ${ }^{1} 152$ of June 12, 1997 [21], article 17 of the Romanian Labour Code [22], the employer must also inform the employee of the duration of the probationary period. A similar duty is assigned to employers in the labour laws of Sweden ( $\$ 6 c$ Employment Protection Act) [20], Finland (section 4 of the Employment Contracts Act) [23] and Romania (article 17 of the Labour Code) [22].

Moreover, according to article L.121-4(2) of the Luxembourg Labour Code, the employer must inform the employee not only of the maximum length of the test period, but also of nonessential or additional terms of the contract established by its parties [14].

According to $\$ 34(1)$ of the Estonian Employment Contracts Act, the employer and the employee can agree that the employer incurs additional costs for training the employee compared to the reasonable expenses for training the employee, and the employee must work to reimburse such expenses for the duration agreed with the employer [11]. A similar norm is contained in article 37 of the Labour Code of the Republic of Lithuania [8].

According to article 3(1) of Council Directive 91/533/EEC, an employer must inform employees no later than two months after starting work in writing in the text of an employment contract or separate notice. Otherwise, the employer must submit a written declaration in two months. If the term of the contract does not exceed two months, then the employer at the end of the work should inform the employees about the aforementioned 
working conditions. According to article 5(1) of Directive 2019/1152, most of the above information must be provided to the employee during the first seven calendar days of work. Only the information referred to in $\S \S$, h, i, j, m-o of article 4(2) of Directive 2019/1152 is provided to the employee by the employer during the first month of work.

An analysis of the labour laws of all EU member states showed that in the vast majority of them only Council Directive 91/533 / EEC requirements are enshrined. According to article L.121-4 (1,2) of the Luxembourg Labour Code [14], article 61(1) of the Bulgarian Labour Code [15], article L1242-12 of the French Labour Code [24], §1 of article 29 of the Polish Labour Code [25] and article 40(1) of the labour Latvian Law [26], Section 16 of the Romanian Labour Code [22], Section 103 of the Portuguese Labour Code [27], Section 9 of the Belgian Labour Contracts Act [28], Section 12 of the Croatian Labour Law [29], an employment contract is concluded upon employment only in written form. According to $\S 2$ of Austrian law, the employer must immediately provide the employee with such written information immediately after the appearance of the employment relationship [17]. In accordance with articles L1242-13 of the Labour Code of France, an employment contract is sent to the employee no later than two business days after taking him to work [24]. According to $\$ 5$ (3) of the Estonian Employment Contracts Act, if the information was not provided to the employee before starting work, the employee may demand such information at any time [11].

In accordance with article 44(1) of the Labour Code of the Republic of Lithuania, before starting work, the employer must provide the employee with such information in writing [8].

In accordance with Section 7 of the Malta Employment and Industrial Relations Act, the employer must provide the employee with a signed copy of the employment contract no later than eight business days from the date of its conclusion [10].

In accordance with article 46(1) of the Hungarian Labour Code, the employer must inform the employee in writing no later than fifteen days from the date of employment [30].

According to §37(1) of the Czech Labour Code [12], section §2(1) of the German law [19] and section 1(2) of Italian Legislative Decree [21], the employer must inform the employees in writing no later than one month from the beginning of their work.

According to article 5(1) of the Directive 91/533/EEC, if the above working conditions change, the employer must inform the employees in writing as soon as possible, but no later than one month from the date the said changes come into force. However, in accordance with article 6(1) of Directive 2019/1152, in the event of a change in any conditions of an employment contract, the employer must inform the employee in writing as soon as possible, but no later than the day when such changes take effect. Otherwise, either the employee should benefit from the favourable presumption determined by the member state, which employers will be able to refute; or the employee should be able to file a complaint with the competent authority in order to receive fair compensation in a timely manner.

An analysis of the labour laws of all EU member states showed that in the vast majority of them only Council Directive 91/533/EEC requirements are enshrined. In particular, according to $\S 4(1)$ of the Danish Law [13] or section 66(5) of the Labour Code of Bulgaria [15], section 6 of the Act on Employment Conditions of the Republic of Ireland [16] or §2(6) of the Austrian AVRAG [17], $\$ 37$ of the Czech Labour Code [12] or $\$ 5$ of the Estonian "Act On employment contracts" [11], $\S 3$ of the German Law [19] or section 3 of Italian Legislative Decree [21], section 6e of the Swedish Employment Protection Act [20] or section 4 of the UK Employment Rights Act [31], section 2(6) Dutch Law [13], or \$3-2 of article 29 of the Polish Labour Code [25], section 52 of the Slovenian Labour Relations Act [32] or section 5 of the Decree of the President of Greece [33], §44(1) of the Labour Law Slovakia [34] or article 109 of the Labour Code of Portugal [27], in case of changes in these conditions, the 
employer must notify the employee in written form as soon as possible, but no later than a month after the entry into force of such changes.

However, according to article L.121-4(4) of the Luxembourg Labour Code, if subsequently changes are made to the conditions of the concluded labour contract, they must be specified in the annex to the written contract, which is also in duplicate and comes into force from the moment signing it [14].

According to section4 of the Finnish Employment Contracts Act, the employer must provide the employee with a written explanation of any change in the conditions of employment as soon as possible, but no later than the end of the pay period following the change, unless the change is a result of a change in legislation or a collective agreement [23].In accordance with article L1222-6 of the French Labour Code, if the employer wishes to change the essential conditions of the labour contract, they must make such offer to the employee by registered letter confirming its receipt [24].

\section{Discussion}

An analysis of the labour laws of all EU member states has given us reasons to propose a number of changes to raise awareness of workers about their rights at work.

Firstly, it is advisable to oblige employers to inform employees, working for them, on the terms of an urgent labour contract about the appearance of a vacant position, which provides the conclusion of a contract for an indefinite period. This obligation is imposed on employers in accordance with article 7:657 of the Dutch Civil Code [13].

Secondly, it is advisable not only to limit the total duration of the probationary period, but also to prohibit re-installing it. For example, according to article 25 of the Labour Code of the Republic of Poland, it is possible to re-establish a probationary period with the same employee only in the following cases: 1) if he has to perform other types of work; 2) not earlier than three years from the date of termination or expiration of the previous employment contract, if the employee is employed to perform the same type of work [25].

Third, when concluding an employment contract, employees should be informed about the method of fixing their arrival at work or their absence from the workplace. Such an obligation is specified in article 29 of the Labour Code of Poland [25].

Fourthly, the employee should be informed about who he will be subordinate in performing his job duties, as it is specified in article 46 of the Hungarian Labour Code [30].

Fifth, in pursuance of the provisions of article 2(b) of the European Pillar of Social Rights [5], we suggest that employers must be obligated, when forming the terms of an employment contract, to observe the principle of equal pay and other working conditions applicable to all employees, regardless of their status.

\section{Conclusions}

Summarizing the results of a comparative analysis of the labour legislation of all EU member states with the Directive 2019/1152 on transparent and predictable working conditions in the European Union, we can draw the following conclusions. 1) By announcing and guaranteeing the realization of the right of workers to receive written information about their labour rights and obligations before starting work, the European Union, on the one hand, answers the challenges of a globalized economy and equips them with a modern tool to protect their labour rights, and on the other hand, contributes to the effective exercise by employees of their economic, social, cultural, political rights. 2) The labour laws of all 28 EU member states are in accordance with Directive 91/533/EEC. However, it did not become the same. Each country in its own way determined the categories of persons who are employees, 
filled in its content the obligation of the employer to inform them of the most important conditions of the employment contract, determined the form and the terms during which the employer is obliged to inform the workers about the conditions of their work, as well as the time of informing them about changes in working conditions. 3) Directive 2019/1152 on transparent and predictable working conditions in the European Union provides a higher level of guarantees for the exercise of the right of workers to receive information on their working conditions and covers a wider range of people than Directive 91/533/EEC and the national labour legislation of most EU member states. Most often, this discrepancy is due to the lack of an obligation on the part of the employer to inform employees about the training that is provided (should be provided) by the employer; overtime pay; a social security institution that receives social security contributions and provides social protection for workers.

\section{References}

[1] Report of the Special Rapporteur on the rights to freedom of peaceful assembly and of association, point 17. United Nations. General Assembly A/71/385. Available: http://www. un.org/ga/search/view_doc. asp?symbol=A/71/385\&Lang=E

[2] Charter of Fundamental Rights of the European Union, 26.10.2012 Official Journal of the European Communities C326, 398. Available: https://eur-lex.europa. eu/legal-content/EN/TXT/PDF/?uri=CELEX : 12012P/TXT\&rid=1

[3] Council Directive 91/533/EEC on an employer's obligation to inform employees of the conditions applicable to the contract or employment relationship, 18.10.1991 Official Journal of the European Communities L288, 32-35. Available: https://eur-lex. europa.eu/legal-content/EN/TXT/?uri=CELEX : 31991L0533

[4] Staff Working Document REFIT Evaluation of the 'Written Statement Directive' (Directive 91/533/EEC). Available: http://ec.europa.eu/social/BlobServ let?docId=17658\&langId=en

[5] Interinstitutional Proclamation on the European Pillar of Social Rights, 13.12.2017 Official Journal of the European Communities C428, 10-15. Available: https:// eur-lex.europa.eu/legal-content/EN/TXT/?uri=uriserv:OJ.C_. 2017.42 8.01.0010.01. ENG\&toc $=0 \mathrm{~J}: \mathrm{C}: 2017: 428:$ TOC

[6] Directive 2019/1152 of the European Parliament and of the Council on transparent and predictable working conditions in the European Union, 11.7.2019 Official Journal of the European Communities L186, 105-121. Available: https : / eur-lex . europa.eu/legal-content/EN/TXT/?uri=uriserv:OJ.L_.2019.186.01.010 5.01. ENG\&toc $=0 \mathrm{~J}: \mathrm{L}: 2019: 186:$ FULL

[7] Judgments of the Court of Justice of 17 November 2016, Betriebsrat der Ruhrlandklinik gGmbH v Ruhrlandklinik gGmbH, C-216/15, ECLI:EU:C:2016:883; 9 July 2015, Ender Balkaya v Kiesel Abbruch- und Recycling Technik GmbH, C-229/14, ECLI:EU:C:2015:455

[8] Lietuvos Respublikos Darbo Kodeksas, TAR2016-09-19 № 23709. Available: https://e-seimas.lrs.1t/rs/actualedition/10c6bfd07bd511e6a0f68fd1 35e6f40c/pJzQBvxgoA/format/ISO_PDF

[9] Real Decreto Legislativo $2 / 2015$, de 23 de octubre, por el que se aprueba el texto refundido de la Ley del Estatuto de los Trabajadores. Available: https://www . boe.es/buscar/act.php?id=BOE-A-2015-11430

[10] Employment and Industrial Relations Act. Available: http://www.justice services.gov .mt/DownloadDocument . aspx?app=lom\&itemid=8918\&l=1 
[11] Töölepingu seadus, RTI 17.12.2015. Available: https://www.riigiteataja. ee/akt/117122015084

[12] Zákon zákoník práce № 262/2006. Available: https://www.zakonyprolidi. $\mathrm{cz} / \mathrm{cs} / 2006-262$

[13] Lov om arbejdsgiverens pligt til at underrette lønmodtageren om vilkårene for ansættelsesforholdet, LBK № 240 af 17/03/2010. Available: https://www . retsinformation.dk/Forms/R0710. aspx?id=130583

[14] Code du Travail Luxembourg. Available: http://data.legilux.public.lu/ file/eli-etat-leg-code-travail-20190201-fr-pdf.pdf

[15] Кодекс на труда България, ДВ. бр.26от 1 Април 1986 г. Available: https://lex.bg/bg/laws/ldoc/1594373121

[16] Terms of Employment Act 1994 № 5, S.I. № 69 of 1994. Available: http:// revisedacts. lawref orm. ie/eli/1994/act/5/revised/en/html

[17] Arbeitsvertragsrechts-Anpassungsgesetz, BGB1 № 235/1993. Available: https:// www. jusline.at/gesetz/avrag

[18] A law to provide for the employer's obligation to inform employees of the particulars of their contract of employment or their employment relationship. Available: http://www.mlsi.gov.cy/mlsi/dlr/dlr.nsf/All/543AD69513B3D85CC2257 A8000213D6F/\$file/Employee\%20information.pdf?OpenElement

[19] Das Arbeitnehmerüberlassungsgesetz, Bundesgesetzblatt, Jahrgang 1995, Teill, S.946. Available: http://www.bgbl. de/xaver/bgbl/start . xav?startbk=Bundesanz eiger_BGB1\&jumpTo=bgbl195s0946.pdf

[20] Lag om anställningsskydd, Svensk författningssamling SFS1982:80. Available: https://www.riksdagen.se/sv/dokument-lagar/dokument/svensk-forfat tningssamling/lag-198280-om-anstallningsskydd_ sfs-1982-80

[21] Decreto legislativo del 26/05/1997 № 152, attuazione della direttiva 91/533/CEE, Gazzetta Ufficiale № 135 del 12 giugno 1997. Available: http://www . camera.it/ parlam/leggi/deleghe/97152dl.htm

[22] L. Codul Muncii, P53/24 ianuarie 2003. Available: http://www.dsclex.ro/ coduri/cm.htm

[23] Employment Contracts Act of Finland. Available: https://www.finlex.fi/ en/laki/kaannokset/2001/en20010055.pdf

[24] Code du Travail. Available: https://www.legifrance.gouv.fr/affichCode. do; jsessionid=C95176D8CB38624ECB9ED6DCEC12B232.tplgfr31s_2?cidText e=LEGITEXT000006072050\&dateTexte $=20190202$

[25] Kodeks pracy, Dz.U.z 2017 r.poz. 1523. Available: http://isap.sejm.gov.pl/ isap.nsf/download.xsp/WDU20180000108/T/D20180108L . pdf

[26] Darba likums, Latvijas Vēstnesis 105, 06.07.2001. Available: https://likumi.lv/ ta/id/26019-darba-likums

[27] Código do Trabalho, Diário da República № 197/2003, Série I-A de200308-27. Available: https://dre.pt/web/guest/pesquisa/-/search/632906/ details/normal?p_ p_ auth=iFf5BFsV

[28] Loi du 3 juillet 1978 relative aux contrats de travail, Conseil d'Etat 22-08-1978 P.9277. Available: https://www.ilo.org/dyn/natlex/docs/ELECTRONIC/13103/7533 2/F-1899924351/BEL-13103.pdf

[29] Zakon o Radu, Narodne novine № 149/2009. Available: https://narodnenovine.nn.hr/clanci/sluzbeni/2009_12_149_3635.html

[30] Labor Code. Available: https://www.ilo.org/dyn/natlex/docs/ELECTRONIC/ 89886/103370/F373393512/Act.I. of .2012.on. the.Labor.Code.2018.pdf 
[31] The Employment Rights Act 1996. Available: https://www.legislation. gov.uk/ukpga/1996/18/part/I

[32] Zakon o delovnih razmerjih, Uradni list RS, št.21/13 z dne 13.3.2013. Available: http://www.pisrs.si/Pis.web/pregledPredpisa?id=ZAK05944

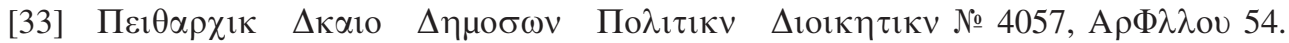
Available: https://www.ilo.org/dyn/natlex/docs/ELECTRONIC/99705/1191 17/F2038881283/GRC99705\%20Grk.pdf

[34] Zákonník Práce, Z.z. № 311/2001. Available: https://www.slov-lex.sk/ pravne-predpisy/SK/ZZ/2001/311/ 